\title{
CORRESPONDENGE
}

The Editor,

\section{Journal of Glaciology}

SIR,

\author{
Patterned ground in Antarctica
}

I have read with interest two recent letters in this journal concerning moraines of a lobe of the Taylor Glacier, Victoria Land. ${ }^{\mathrm{I}, 2}$

The photograph published by Harrington and Speden ${ }^{3}$ is of special interest because of the patterned ground to be seen on it. Dr. H.J. Harrington (personal communication) has kindly outlined evidence on which he and Mr. Speden defend a very recent origin for the soil polygons, contrary to the suggestion by Blake and Hollin ${ }^{4}$ that these indicate a long period since the withdrawal of the ice.

The situation is similar to circumstances which I have observed in the Shackleton Range, Weddell Sea, and a brief note on patterned ground occurrence there may be of interest, particularly since these phenomena had suggested to me what is a third possible interpretation.

Figures I and 2 (p. I I 64) show typical patterned ground near the western end of the Shackleton Range. Unsorted polygons and stripes (on steeper ground) are developed. Both are raised, hummock-like features quite different from the sand-wedge polygons described from McMurdo Sound by Péwé. ${ }^{5}$ In places the patterned ground occurs adjacent to small ice fields which appear from their isolation and shape to be diminishing. The patterned ground immediately adjacent to this ice cover is just as well developed as that some distance away. Also, the polygon and stripe patterns appear to be interrupted abruptly at the margin of the ice. These relationships deny rapid formation of the polygons and stripes, and suggest instead that fully developed patterned ground is being uncovered as the ice diminishes.

The occurrence of fully developed patterned ground beneath the ice may indicate either that the patterned ground is being formed by some subglacial processes, or that the features are of fossil origin. None of the mechanisms suggested for patterned ground formation (reviewed by Washburn $)^{6}$ can be expected to operate subglacially under present climatic conditions in the Shackleton Range, where the annual mean temperature is well below freezing point and temperature fluctuation beneath more than ro $\mathrm{m}$. of ice must be negligible.

It seems therefore that the patterned ground is of fossil origin. I considered it to represent a former interglacial period, the age of which is uncertain. Since patterned ground is developed on all but the most recent erosion surfaces in the Shackleton Range, the interglacial appears to be younger than the important one suggested by Péwé 7 for the McMurdo Sound region.

Another item of evidence concerns the presence of gypsum as a subsurface crust in some of the soils associated with patterned ground. This can only have been formed under conditions allowing some ground water movement. Under present conditions this is denied, and the gypsum, like the polygons and stripes, must surely be a relic from an interglacial.

Geology Deparlment,

University College, Torensville, Queensland, Australia

19 January 1961

P. J. STEPHENSON

(Commonwealth Trans-Antarctic Expedition, 1955-58)

\section{REFER E N CES}

I. Harrington, H. J., and Speden, I. G. Recent moraines of a lobe of the Taylor Glacier, Victoria Land, Antarctica. Journal of Glaciology, Vol. 3 , No. 27, 1960, p. 652-53.

2. Blake, W., jr., and Hollin, J. Recent moraines of a lobe of the Taylor Glacier, Victoria Land, Antarctica. fournal of Glaciology, Vol. 3, No. 28, 1960, p. 792-93.

3. Harrington, H. J., and Speden, I. G. op. cit., p. 652.

4. Blake, W., jr., and Hollin, J. op. cit., p. 792-93.

5. Péwé, T. L. Sand-wedge polygons (tesselations) in the McMurdo Sound region, Antarctica - a progress report. American Journal of Science, Vol. 257, No. 8, 1959, p. 545-52.

6. Washburn, A. L. Classification of patterned ground and review of suggested origins. Bulletin of the Geological Society of America, Vol. 67, No. 7, 1956, p. 823-66.

7. Péwé, T. L. Multiple glaciation in the McMurdo Sound region, Antarctica-a progress report. Journal of Geology, Vol. 68, No. 5, 196o, p. 498-514. 


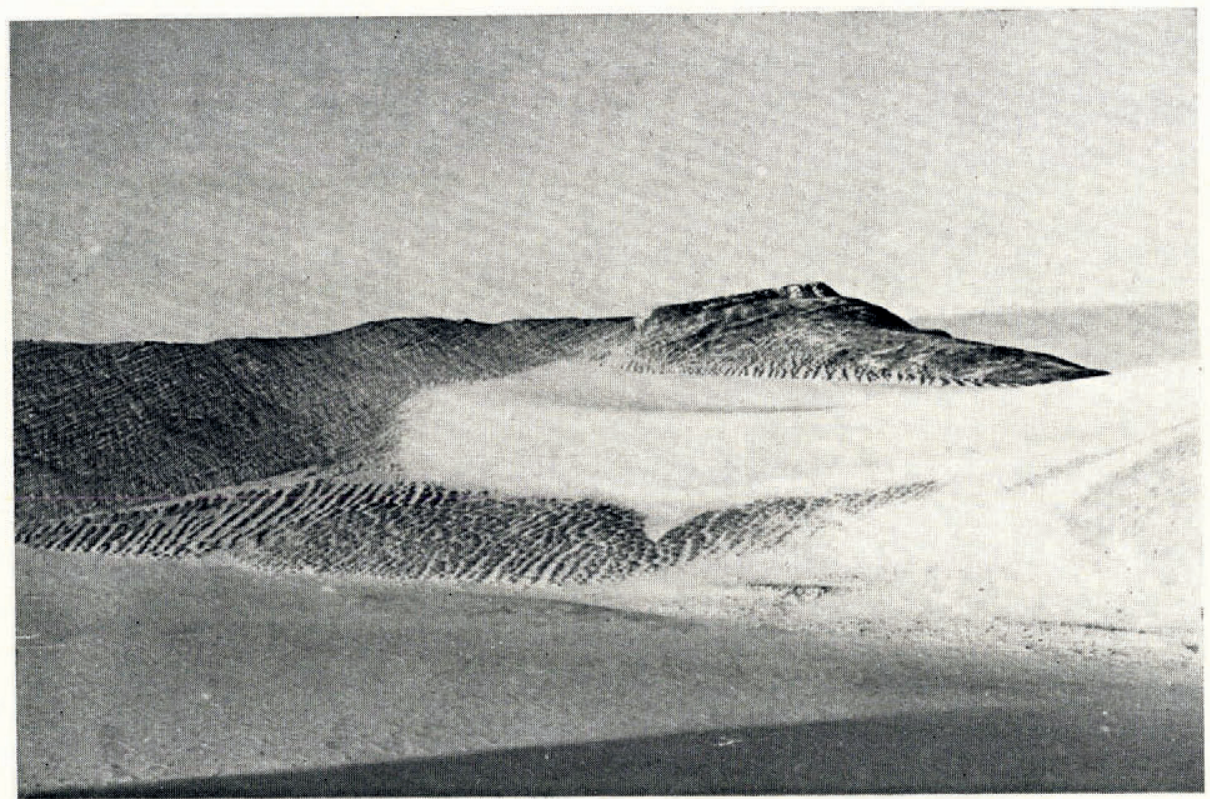

Fig. 1. Patterned ground on a mountain in the Shackleton Range, October 1.957. Note the abrupt interruption of the patterned ground against the margins of the smaller ice field

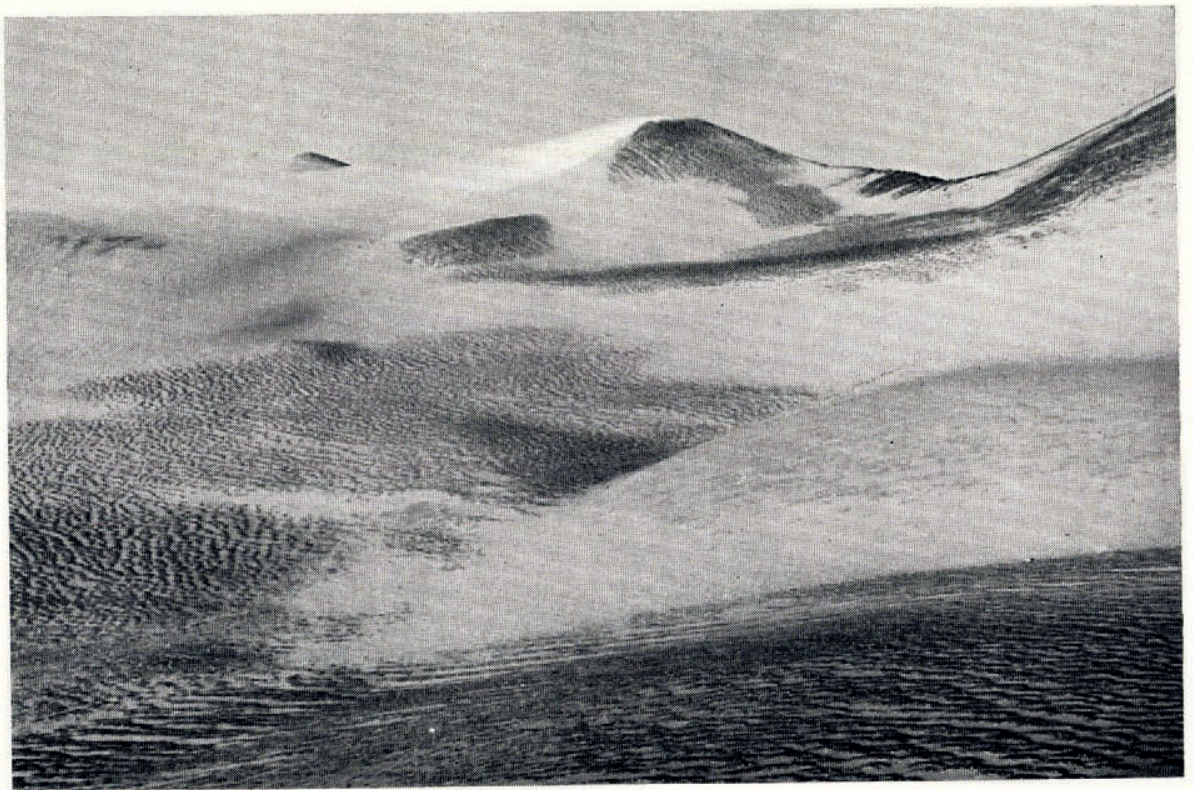

Fig. 2. Patterned ground in the Shackleton Range, October 1957. Note its relationship to the margin of the ice lobe in the foreground 